Ion Exchange and Dehydration Experimental Studies of Clinoptilolite: Implications to Zeolite Dating

Giday WoldeGabriel

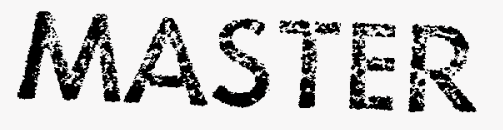




\section{DISCLAIMER}

This report was prepared as an account of work sponsored by an agency of the United States Government. Neither the United States Government nor any agency thereof, nor any of their employees, make any warranty, express or implied, or assumes any legal liability or responsibility for the accuracy, completeness, or usefulness of any information, apparatus, product, or process disclosed, or represents that its use would not infringe privately owned rights. Reference herein to any specific commercial product, process, or service by trade name, trademark, manufacturer, or otherwise does not necessarily constitute or imply its endorsement, recommendation, or favoring by the United States Government or any agency thereof. The views and opinions of authors expressed herein do not necessarily state or reflect those of the United States Government or any agency thereof. 


\section{DISCLAIMER}

Portions of this document may be illegible in electronic image products. Images are produced from the best available original document. 


\title{
ION EXCHANGE AND DEHYDRATION EXPERIMENTAL STUDIES OF CLINOPTILOLITE: IMPLICATIONS TO ZEOLITE DATING \\ by

\author{
Giday WoldeGabriel
}

\begin{abstract}
Variable effects were noted on the argon (Ar) and potassium (K) contents of clinoptilolite fractions used in ion-exchange and dehydration experiments. The $\mathrm{K}$ contents of clinoptilolite fractions were differently affected during cation exchange with $\mathrm{Ca}-, \mathrm{Cs}-, \mathrm{K}-$, and $\mathrm{Na}$-chloride solutions. Ar was generally less affected during these experiments, except for a Na-clinoptilolite fraction exchanged for five days. Loss of Ar during organic heavy-liquid treatment and cleaning using acetone and deionized water does occur, as indicated by comparing the amounts of radiogenic Ar of treated and untreated fractions. Moreover, a regular decrease in radiogenic $\mathrm{Ar}$ contents was noted in clinoptilolite fractions during dehydration experiments at different temperatures for 16 hours. Comparable losses do not occur from saturated samples that were heated in $100^{\circ} \mathrm{C}$ for more than five months.

Water appears to play a vital role in stabilizing the clinoptilolite framework structure and in the retention of Ar. The radiogenic Ar depletion pattern noted in clinoptilolite fractions dehydrated in unsaturated environment at different temperatures is similar to variations in the amount of radiogenic Ar observed in clinoptilolite samples from the unsaturated zone of an altered tuff. These results can be used to evaluate the extent of zeolitic water (and hence Ar) retention in unsaturated geologic settings.
\end{abstract}

\section{INTRODUCTION}

Zeolites are open-framework aluminosilicate minerals, generally formed at low temperatures, that are utilized widely in various environmental research applications for their adsorptive, molecular sieve, ion-exchange, and catalytic properties (Mumpton, 1978). The origin 
and distribution of zeolites are generally well established; however, the timing of diagenesis is often poorly constrained.

Published information on zeolite dating is very sparse considering the widespread occurrences and importance of these industrial minerals. The presence of large cavities and channels in zeolites that allow cations, water molecules, and certain gases to move readily in and out of the crystal structure (e.g., Vaughan, 1978; Feng and Savin, 1993) implies the existence of poor $\mathrm{Ar}$ and $\mathrm{K}$ retention and this may explain the limited research in zeolite dating by the $\mathrm{K} / \mathrm{Ar}$ and similar methods. However, zeolite diagenesis in the early Miocene John Day Formation of Oregon was indirectly determined by dating the coexisting K-bearing silicate minerals of authigenic feldspar and celadonite (Hay, 1963). Limited studies on $\mathrm{K} / \mathrm{Ar}, \mathrm{Rb} / \mathrm{Sr}$, and fission track dating of phillipsite, clinoptilolite, heulandite, stilbite, and chabazite separated from deep-sea and continental sediments, and from vesicles in basaltic lavas have also been described (Bernat et al., 1970; Koul et al., 1981; Clauer, 1982; Gundogdu et al., 1989).

The utility of alkali zeolites (e.g., phillipsite, clinoptilolite, and mordenite) from lowtemperature, open-hydrologic alteration as potential dateable minerals was evaluated using the $\mathrm{K} / \mathrm{Ar}$ method as part of the Yucca Mountain Site Characterization Project, which is evaluating Yucca Mountain, Nevada, as a potential high-level radioactive waste repository site (WoldeGabriel et al., 1993). The presence of zeolites was a major reason for choosing the site because these minerals provide favorable physical and chemical properties as important barriers to radionuclide migration. Thus, it is judicious to determine the time of diagenesis of zeolite and other coexisting minerals to understand the geologic history of the site. Authigenic minerals such as illite, illite/ smectite, Kfeldspar, etc., are generally dated to constrain burial and thermal alteration histories of rocks in various geological settings (e.g., Hoffman et al., 1976; WoldeGabriel and Goff, 1989; Elliot et al., 1991; Bish and Aronson, 1993). Thus, dating of K-bearing zeolites and other coexisting dateable minerals from Yucca Mountain could provide the diagenetic ages of these minerals to understand the geologic history of the site.

Information on temperature and pressure conditions during zeolite diagenesis can often be inferred from authigenic silicate mineral assemblages, burial depth, and vitrinite reflectance data (Iijima, 1978; Bell, 1986; Turner and Fishman, 1991). Temperature is important in controlling 
zeolite stability, whereas pressure appears to have a minimal effect as indicated by the occurrences of particular zeolites throughout a broad range of burial depths (Boles, 1977). Because the dominant authigenic minerals (smectite, clinoptilolite, opal-CT, etc.) at Yucca Mountain are characteristic of low-temperature diagenetic environments with upper stability limits of about $100^{\circ} \mathrm{C}$ (Ijima, 1978; Bish, 1989), accurate ages on the K-bearing zeolites and other coexisting dateable minerals could also provide information on post-diagenetic processes and the past and future thermal history of the site.

Clinoptilolite fractions separated from outcrop and drill core samples of altered tuffs from Yucca Mountain and dated by the K/Ar method yielded variable isotopic ages (WoldeGabriel et al., 1993). Some of the clinoptilolite isotopic ages (9-12 Ma) from the saturated zone are generally similar to the eruption ages of the tuffs; however, those from the unsaturated zone have apparent ages that are much younger (2-5 Ma). Although the dated clinoptilolite fractions have the same mineralogy in both the saturated and the unsaturated zones, the factors responsible for the isotopic age variations are not fully understood. However, water appears to play a significant role in zeolite stability (Boles, 1972; Bish, 1988), and the difference in isotopic ages may be related to loss of water and then argon from the structural cavities of clinoptilolite in the unsaturated environment. Water molecules in the extraframework sites in clinoptilolite may in fact inhibit or slow the migration of extraframework Ar.

Because the K-bearing clinoptilolite fractions from outcrop and the unsaturated zone yielded younger isotopic ages, it is essential to evaluate the effects of cation exchange and variable saturation on the $\mathrm{K}^{+}$and Ar contents of these minerals. Thus, the objective of this study was to evaluate experimentally the effects of post-crystallization ion-exchange and dehydration processes on $\mathrm{K}^{+}$and Ar contents of clinoptilolite. Significant effects might be anticipated because zeolites are characterized by an open-framework structure with a large ion-exchange capacity.

\section{EXPERIMENTAL METHODS}

The clinoptilolite-rich bulk sample used in the ion-exchange and dehydration experiments for the present study is from the late Miocene Sucker Creek Formation of Sheaville, eastern Oregon, that formed in an open hydrologic system from percolating meteoric fluids (Sheppard et 
al., 1983). The sample was chosen for its purity and is unlike the clinoptilolite-rich samples from Yucca Mountain that coexist with other diagenetic minerals. The time of zeolite formation in the Sucker Creek Formation is unknown; however, it is suggested that the alteration of silicic tuffs to zeolites in an open system occurs during early diagenesis (Hay, 1978). Both K- and Caclinoptilolites are present in the altered tuff units and it is reported that these zeolites were affected by post-diagenetic low-temperature $\left(75-100^{\circ} \mathrm{C}\right)$ hydrothermal alteration that resulted in cation exchange in the zeolites and the formation of quartz from opal-CT (Altaner and Grim, 1990). The clinoptilolite sample (27073) was obtained from Minerals Research, P. O. Box 591, Clarkson, New York, 14430 USA.

In most cases, zeolites were separated from coexisting authigenic silicate minerals by sedimentation in deionized water. Additional purification was carried out using organic heavy liquids. Clinoptilolite was thoroughly mixed with S-tetrabromoethane to evaluate the effect of the heavy liquid on the framework structure of the mineral during clinoptilolite purification. The heavy-liquid treated aliquot was thoroughly cleaned using acetone in an ultrasonic bath followed by centrifugation before it was cleaned with deionized water.

For the ion-exchange experiments, $1 \mathrm{M}$ chloride solutions of $\mathrm{Ca}^{2+}, \mathrm{K}^{+}, \mathrm{Na}^{+}$, and $\mathrm{Cs}^{+}$were prepared and added to several splits of bulk (i.e., not enriched by separation) clinoptilolite aliquots $(5-50 \mathrm{~m})$. The mixture was placed in an oven at $50^{\circ} \mathrm{C}$ and periodically shaken during the $24-\mathrm{hr}$ ion-exchange experiment. New batches of chloride solutions were added every 24 hours after the exchanged solution was removed by centrifugation. The experiments were conducted in 3 and 5 steps for total times of 72 and 120 hours, respectively. A clinoptilolite bulk powder and the solutions obtained by centrifugation after each of the ion-exchange experiments were analyzed for cations (e.g., $\mathrm{Ca}^{2+}, \mathrm{Cs}^{+}, \mathrm{K}^{+}$, and $\mathrm{Na}^{+}$) and major-element concentrations. Samples from the ionexchange treatment were thoroughly cleaned using deionized water in an ultrasonic bath followed by centrifugation. The bulk powder was analyzed by X-ray fluorescence spectrometry and the exchange solutions were measured by atomic absorption spectrophotometry, combined with gravimetric determinations, along with bulk rock and solution standards.

Aliquots of about $2 \mathrm{~g}$ of clinoptilolite from the same bulk sample used in the ion-exchange experiment were heated to $50,100,150$, and $200^{\circ} \mathrm{C}$ in air for 16 hours. The samples were kept in 
a desicator until they were analyzed for $\mathrm{K}$ and Ar. Additional heating experiments were conducted on other aliquots from the same sample held in deionized water ( 2 to 1 water/sample ratio) for a week, a month, three months, and about six months at $100^{\circ} \mathrm{C}$. All samples from the experiments were X-rayed using an automated Siemens D-500 diffractometer with $\mathrm{Cu} \mathrm{K}$ radiation, $0.02^{\circ} 2 \theta$ steps, and a counting time of 1 s per step for all mounts $\left(2-36^{\circ} 2 \theta\right)$.

The $\mathrm{K}_{2} \mathrm{O}$ contents were determined using an atomic absorption spectrophotometer on 70 to $100 \mathrm{mg}$ of sample, and aliquots of about 120 to $250 \mathrm{mg}$ of the same sample were used for the radiogenic Ar measurements using an MS10 mass spectrometer on line with bulb-pipetted ${ }^{38} \mathrm{Ar}$. The K/Ar system was prebaked while samples were cooled by running water. Standard samples (e.g., BCR-1, G-2, and LP-6) analyzed with the unknown samples for $\mathrm{K}_{2} \mathrm{O}$ and Ar varied by less than 2.5 from the published values (Odin et al., 1982; Govindaraju, 1989).

\section{RESULTS}

Heavy-liquid treated and ion-exchanged clinoptilolite fractions showed no apparent changes in their XRD patterns compared with the untreated sample. This is also true for samples heated under unsaturated and saturated conditions at variable temperatures for 16 hours and more than five months, respectively (Fig. 1).

Results of chemical analysis of the untreated clinoptilolite fraction and a standard sample and published results of the standard (NIM-G) are given in Table 1, and the $5.34 \mathrm{wt} \% \mathrm{~K}_{2} \mathrm{O}$ of the clinoptilolite is used as a reference to evaluate the extent of potassium enrichment and depletion during the ion-exchange experiments. The chemical compositions of the solutions obtained by centrifugations after each of the 24-hr Ca-, Cs- K-, and Na-chloride solution exchanges are given in Table 2. The results indicate that the alkali and alkaline earth cations were replaced stepwise, with most replacement occurring during the first phase of the ion-exchange experiment and exchange decreasing substantially during subsequent steps (Fig. 2).

Results of $\mathrm{Ca}^{2+}$ analysis from the Cs-, $\mathrm{K}-$, and Na-exchanged solutions indicate that similar amounts of $\mathrm{Ca}^{2+}$ were replaced by these cations (Table 2 and Fig. 2a). Clinoptilolite shows a greater affinity for $\mathrm{Cs}^{+}$, with $\mathrm{Na}^{+}$replacing slightly more $\mathrm{K}^{+}$than $\mathrm{Ca}^{2+}$ (Fig. 2b). More $\mathrm{Na}^{+}$was replaced by $\mathrm{Cs}^{+}$and $\mathrm{K}^{+}$during the first step of the exchange experiment compared with $\mathrm{Ca}^{2+}$ 


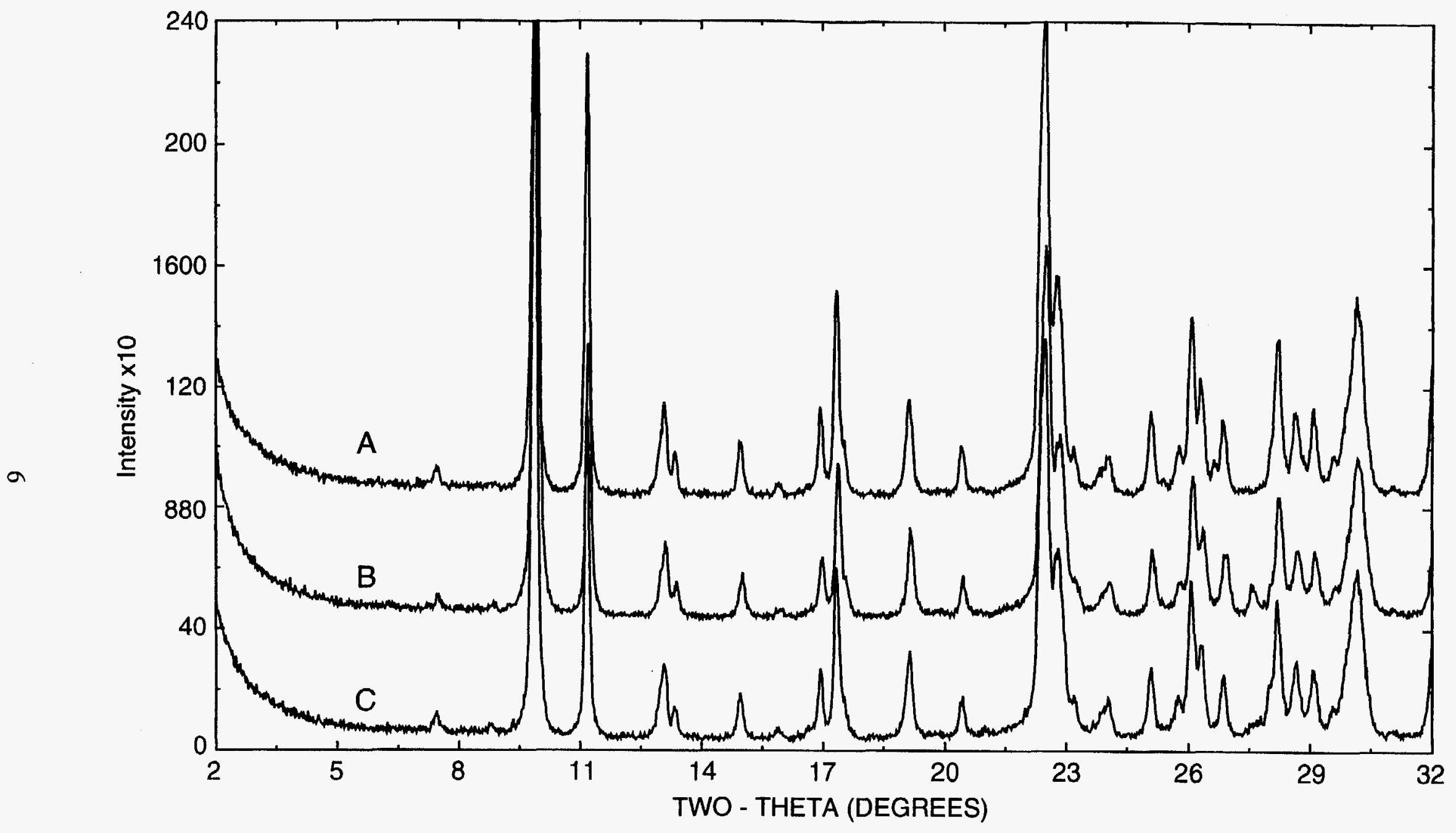

Figure 1. X-ray diffraction patterns of clinoptilolite fractions used in the dehydration and ion-exchange experiments. The patterns are for unsaturated heating at $200^{\circ} \mathrm{C}(\mathrm{A})$, saturated heating at $100^{\circ} \mathrm{C}$ for more than five months (B), and an untreated fraction (C). 
Table 1. Major-element composition of clinoptilolite-rich bulk sample in weight percent used for ion-exchange and dehydration experiments. Clinoptilolite and standard sample NIM-G analyzed using X-ray fluorescence to check the analytical data against published information.

\begin{tabular}{|l|c|c|c|}
\hline & $27073 / \mathrm{CPT} \# 1$ & NIM-G & NIM-G \\
\cline { 2 - 4 } $\mathrm{SiO}_{2}$ & 64.62 & 75.70 & 75.70 \\
$\mathrm{TiO}_{2}$ & 0.07 & 0.059 & 0.09 \\
$\mathrm{Al}_{2} \mathrm{O}_{3}$ & 12.22 & 12.20 & 12.08 \\
$\mathrm{Fe}_{2} \mathrm{O}_{3}$ & 0.42 & 0.49 & 0.58 \\
$\mathrm{FeO}$ & 0.03 & 1.27 & 1.30 \\
$\mathrm{MnO}$ & 0.03 & 0.01 & 0.02 \\
$\mathrm{MgO}$ & 0.28 & 0.03 & 0.06 \\
$\mathrm{CaO}$ & 1.43 & 0.78 & 0.78 \\
$\mathrm{Na}_{2} \mathrm{O}$ & 1.77 & 3.39 & 3.36 \\
$\mathrm{~K}_{2} \mathrm{O}$ & 5.34 & 5.02 & 4.99 \\
$\mathrm{H}_{2} \mathrm{O}^{-}$ & 4.19 & 0.52 & 0.49 \\
$\mathrm{H}_{2} \mathrm{O}^{+}$ & 8.40 & 0.0 & 0.01 \\
$\mathrm{P}_{2} \mathrm{O}_{5}$ & 0.01 & 0.01 & 0.0 \\
$\mathrm{BaO}^{\mathrm{SrO}}$ & 0.23 & 0.01 & \\
\hline & 0.03 & $<0.004$ & \\
Total & 99.03 & 99.41 & 99.46 \\
\hline
\end{tabular}

†Published major element composition of standard NIM-G included for comparison (Govindaraju, 1989).

(Fig. 2c). These results are generally consistent with the cation affinity sequence for clinoptilolite reported by Ames (1961).

Radiogenic Ar contents of clinoptilolite fractions from the various experiments are given in Table 3. These values range from $1.1109 \times 10^{-12}$ to $3.7402 \times 10^{-12}$ moles and probably do not represent the amount of radiogenic Ar accumulated since the time of alteration from silicic glass to clinoptilolite because the clinoptilolite fractions were subjected to ion-exchange and heating experiments. The $\mathrm{K}_{2} \mathrm{O}$ contents of the clinoptilolite fractions ( 1 to $9 \mathrm{wt} \%$ ) were significantly modified during the ion-exchange experiments, whereas the radioagenic Ar contents show less drastic variations except for the Cs-clinoptilolite exchanged for five days (Fig. 3a). The Cs- and Na-clinoptilolite fractions exchanged for five days contain larger and smaller amounts of radiogenic Ar, respectively, compared with the other fractions. Moreover, the amount of radiogenic Ar in the heavy-liquid treated fraction is depleted. The rest of the clinoptilolite fractions exchanged for three and five days show similar amounts of radiogenic Ar (Fig. 3a). 
Table 2. Results of analysis (ppm) of solutions from 24-hr ion-exchange experiments using atomic absorption spectrometry. The K-rich clinoptilolite was exchanged for 3 and 5 days with each of the cations listed. Standard WP591\#1 was analyzed for comparison with accepted data. Solutions were changed every 24 hours.

\begin{tabular}{|c|c|c|c|c|c|}
\hline $\begin{array}{l}\text { Chloride } \\
\text { Solutions }\end{array}$ & $\begin{array}{l}\text { Sample ID } \\
(27073 / \text { CPT\#1) }\end{array}$ & $\mathrm{Ca}$ & Cs & $\overline{\mathrm{K}}$ & $\mathrm{Na}$ \\
\hline CaCl2-3 days & $\begin{array}{l}3-1 \\
3-2 \\
3-3 \\
3-3 \text { (duplicate) }\end{array}$ & $\begin{array}{l}>1500 \\
>1500 \\
>1500 \\
>1500\end{array}$ & $\begin{array}{l}<2 \\
<2 \\
<2 \\
<2\end{array}$ & $\begin{array}{l}505 \\
330 \\
240 \\
245\end{array}$ & $\begin{array}{l}690 \\
204 \\
78 \\
80\end{array}$ \\
\hline $\mathrm{CaCl} 2-5$ days & $\begin{array}{l}5-1 \\
5-2 \\
5-3 \\
5-4 \\
5-5\end{array}$ & $\begin{array}{l}>1500 \\
>1500 \\
>1500 \\
>1500 \\
>1500\end{array}$ & $\begin{array}{l}<2 \\
<2 \\
<2 \\
<2 \\
<2\end{array}$ & $\begin{array}{l}512 \\
354 \\
270 \\
222 \\
181\end{array}$ & $\begin{array}{l}672 \\
232 \\
90 \\
42 \\
23\end{array}$ \\
\hline $\mathrm{CsCl}-3$ days & $\begin{array}{l}3-1 \\
3-2 \\
3-3\end{array}$ & $\begin{array}{l}680 \\
140 \\
45\end{array}$ & $\begin{array}{l}>>1000 \\
>>1000 \\
>>1000\end{array}$ & $\begin{array}{l}1750 \\
700 \\
313\end{array}$ & $\begin{array}{l}910 \\
112 \\
24\end{array}$ \\
\hline $\mathrm{CsCl}-5$ days & $\begin{array}{l}5-1 \\
5-2 \\
5-3 \\
5-4 \\
5-5 \\
5-5 \text { (duplicate) }\end{array}$ & $\begin{array}{l}680 \\
135 \\
45 \\
27 \\
15 \\
15\end{array}$ & $\begin{array}{l}>>1000 \\
>>1000 \\
>>1000 \\
>>1000 \\
>>1000 \\
>>1000\end{array}$ & $\begin{array}{l}1740 \\
700 \\
313 \\
194 \\
126 \\
130\end{array}$ & $\begin{array}{l}910 \\
111 \\
24 \\
10 \\
8 \\
8.5\end{array}$ \\
\hline $\mathrm{KCl}-3$ days & $\begin{array}{l}3-1 \\
3-1 \\
3-2 \\
3-3\end{array}$ & $\begin{array}{l}710 \\
710 \\
150 \\
40\end{array}$ & $\begin{array}{l}<1 \\
<1 \\
<1 \\
<1\end{array}$ & $\begin{array}{l}>3500 \\
>3500 \\
>3500 \\
>3500\end{array}$ & $\begin{array}{l}915 \\
940 \\
130 \\
20\end{array}$ \\
\hline $\mathrm{KCl}-5$ days & $\begin{array}{l}5-1 \\
5-2 \\
5-3 \\
5-4 \\
5-5\end{array}$ & $\begin{array}{l}677 \\
160 \\
37 \\
17 \\
8\end{array}$ & $\begin{array}{l}<1 \\
<1 \\
<1 \\
<1 \\
<1\end{array}$ & $\begin{array}{l}>3500 \\
>3500 \\
>3500 \\
>3500 \\
>3500\end{array}$ & $\begin{array}{l}915 \\
149 \\
26 \\
3 \\
<1\end{array}$ \\
\hline $\mathrm{NaCl}-3$ days & $\begin{array}{l}3-1 \\
3-2 \\
3-3\end{array}$ & $\begin{array}{l}670 \\
140 \\
57\end{array}$ & $\begin{array}{l}<1 \\
<1 \\
<1\end{array}$ & $\begin{array}{l}700 \\
433 \\
295\end{array}$ & $\begin{array}{l}>>1000 \\
>>1000 \\
>>1000\end{array}$ \\
\hline $\mathrm{NaCl}-5$ days & $\begin{array}{l}5-1 \\
5-2 \\
5-3 \\
5-4 \\
5-4 \text { (duplicate) } \\
5-5\end{array}$ & $\begin{array}{l}652 \\
170 \\
57 \\
30 \\
30 \\
14 \\
\end{array}$ & $\begin{array}{l}<1 \\
<1 \\
<1 \\
<1 \\
<1 \\
<1\end{array}$ & $\begin{array}{l}707 \\
477 \\
307 \\
235 \\
235 \\
192\end{array}$ & $\begin{array}{l}>>1000 \\
>>1000 \\
>>1000 \\
>>1000 \\
>>1000 \\
>>1000\end{array}$ \\
\hline $\begin{array}{l}\text { WP591\#1* } \\
\text { WP591\#1† }\end{array}$ & $10-1$ & $\begin{array}{l}28 \\
27 \\
\end{array}$ & & $\begin{array}{l}16 \\
16 \\
\end{array}$ & $\begin{array}{l}85 \\
88.4 \\
\end{array}$ \\
\hline
\end{tabular}

* EPA reference standard solution; $†$ Published chemical data for the reference solution 

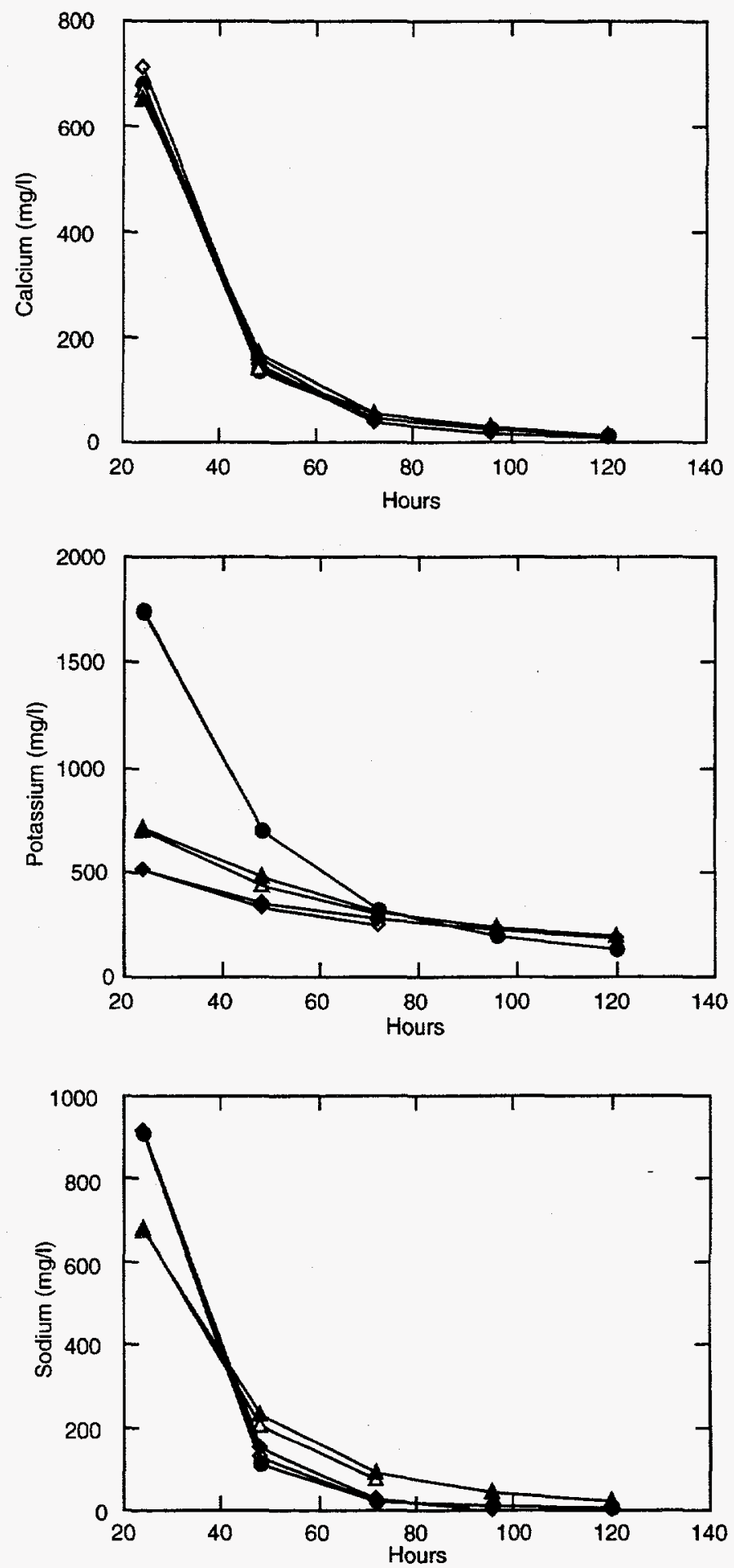

Figure 2. Cation concentrations of $\mathrm{Ca}^{2+}, \mathrm{K}^{+}$, and $\mathrm{Na}^{+}$in solutions from ion-exchange experiments. Ca-, Cs-, K-, Na-chloride solutions were used for three and five days indicated by open and solid circles, respectively. Most of the cations were replaced within 70 hours. Similar amounts of $\mathrm{Ca}^{2+}$ ions were replaced by $\mathrm{Cs}^{+}, \mathrm{K}^{+}$, and $\mathrm{Na}^{+}$in $\mathrm{A}$, whereas $\mathrm{Cs}^{+}$replaced more $\mathrm{K}^{+}$compared with $\mathrm{Ca}^{2+}$ and $\mathrm{Na}^{+}$in $\mathrm{B}$. More $\mathrm{Na}^{+}$ions were replaced by $\mathrm{Cs}^{+}$and $\mathrm{K}^{+}$as shown in $\mathrm{C}$. Circles, triangles, and diamonds represent cations of $\mathrm{Cs}, \mathrm{K}$, and $\mathrm{Na}$ in $\mathrm{A} ; \mathrm{Cs}, \mathrm{Na}$, and $\mathrm{Ca}$ in $\mathrm{B}$; and $\mathrm{Cs}$, $\mathrm{K}$, and $\mathrm{Ca}$ in $\mathrm{C}$. 
Table 3. Radiogenic argon and potassium contents of clinoptilolite fractions from dehydration and cation-exchange experiments.

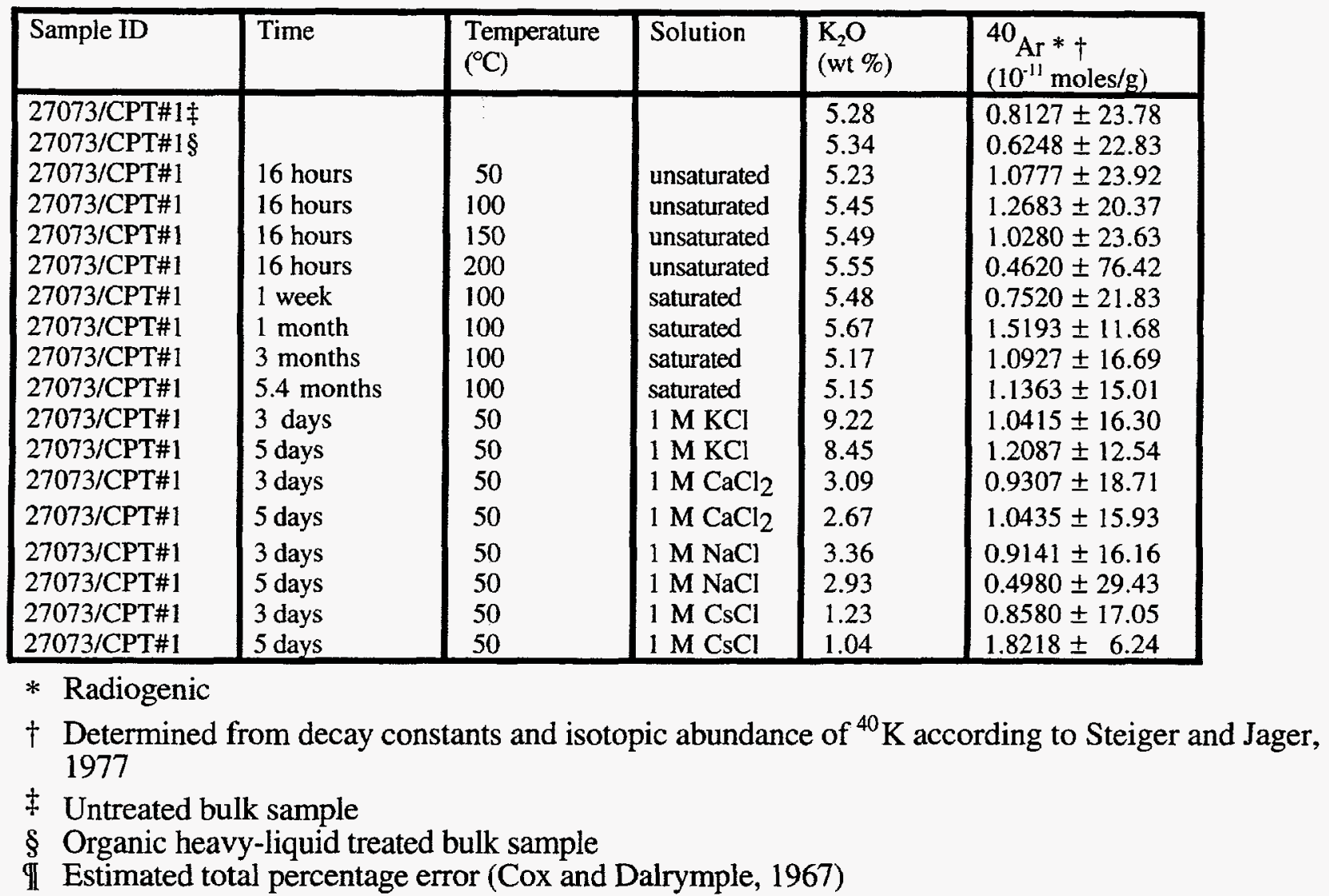

A depletion pattern in the radiogenic Ar contents is noted in the clinoptilolite fractions heated at different temperatures for 16 hours (Fig. 3b). About $70 \%$ of the radiogenic Ar was lost during the heating at $200^{\circ} \mathrm{C}$ compared with the first sample heated at $50^{\circ} \mathrm{C}$, with most of the $\mathrm{Ar}$ diffusing out during the higher temperature $\left(200^{\circ} \mathrm{C}\right)$ heating (Table 3$)$. The clinoptilolite aliquots heated in saturated conditions at lower temperature $\left(100^{\circ} \mathrm{C}\right)$ yielded variable radiogenic $\mathrm{Ar}$ contents, especially those fractions heated for a week and one month (Fig. 3c). The other two fractions heated for longer times contain similar amounts of Ar.

\section{DISCUSSION}

The time of alteration of the silicic tuff to clinoptilolite in the Sucker Creek Formation is unknown. The radiogenic Ar contents for the clinoptilolite fractions reported here are minimum 

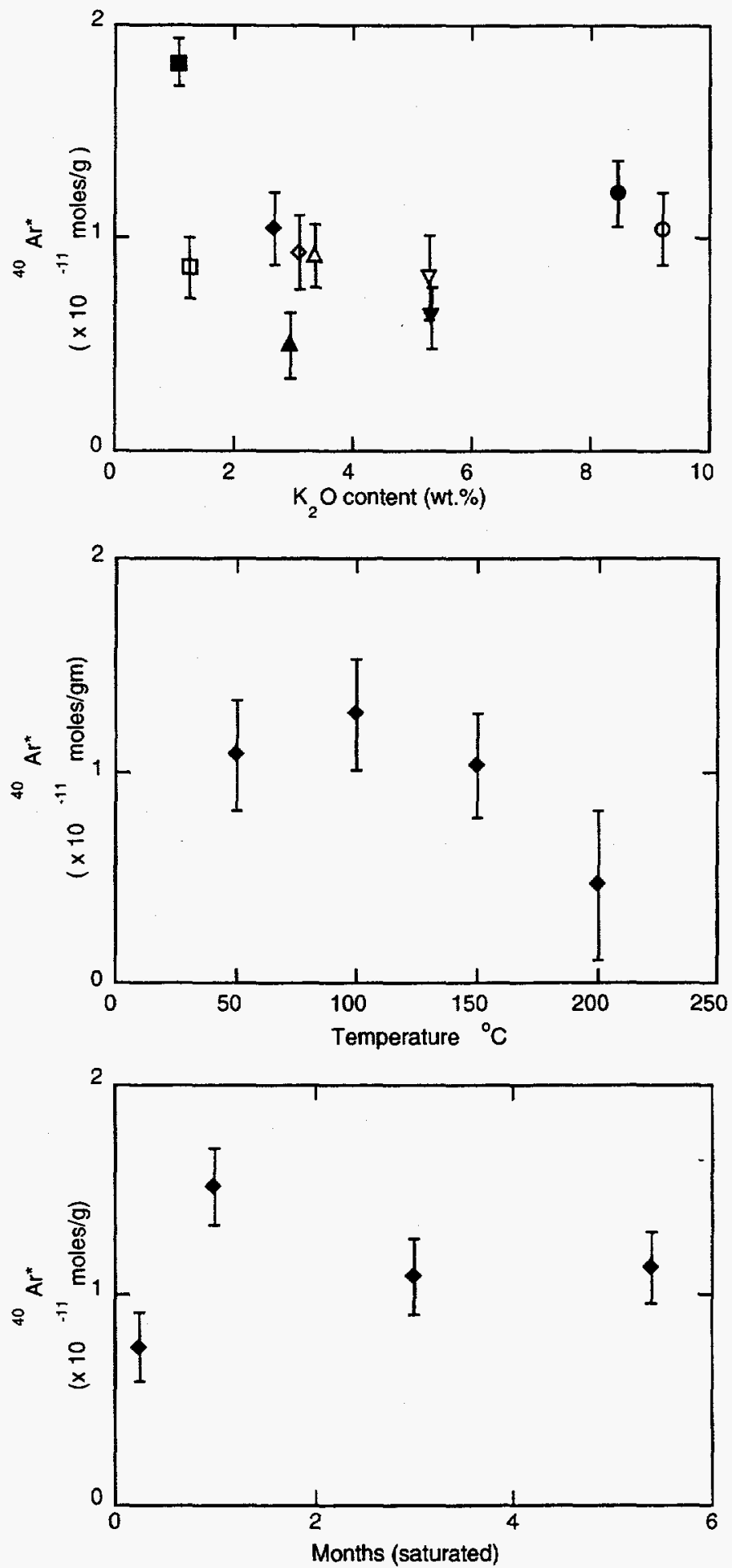

Figure 3. Radiogenic Ar content plots of ion-exchanged clinoptilolite fractions. Except for the inverted triangles, open and solid symbols in (A) represent clinoptilolite fractions ion exchanged for five and three days, respectively. Symbols represent $\mathrm{Ca}^{2+}$ (diamonds), $\mathrm{Cs}^{+}$(square), $\mathrm{K}^{+}$(circle), $\mathrm{Na}^{+}$ (triangle); also shown are untreated (inverted triangle) and heavy-liquid treated (solid inverted triangle) sample results. Other panels show results from unsaturated heating at various temperatures for 16 hours (B) and saturated heating at $100^{\circ} \mathrm{C}$ for several time periods (C). Uncertainties are cumulative percentage errors. 
values and do not represent the amount accumulated since the crystallization of the clinoptilolite from the alteration of the silicic shards. Isotopic ages were not calculated from the measured radiogenic Ar contents of the clinoptilolite fractions because the samples used in ion-exchange and dehydration experiments have modified $\mathrm{K}_{2} \mathrm{O}$ and Ar contents. Calculated apparent isotopic ages from such experiments are thus meaningless. It has been reported that the clinoptilolite and other coexisting minerals in the Sucker Creek Formation were modified by post-diagenetic cation exchange during low-temperature $\left(75-100^{\circ} \mathrm{C}\right.$ ) hydrothermal alteration (Altaner and Grim, 1990). The smaller amounts of radiogenic Ar in the untreated bulk clinoptilolite fraction may thus be related to loss of Ar during the long-term hydrothermal heating of the zeolites. Moreover, loss of water during dehydration in an unsaturated environment appears to enhance loss of radiogenic Ar (WoldeGabriel, et al., 1993).

Zeolite separations from coexisting authigenic quartz, K-feldspar, and clays using sedimentation methods in deionized water and organic heavy liquids have minimal effects on the $\mathrm{K}_{2} \mathrm{O}$ contents of alkali zeolites. This is indicated by the similarity in $\mathrm{K}_{2} \mathrm{O}$ contents of untreated and organic heavy-liquid treated clinoptilolite fractions (Table 3). However, the radiogenic Ar content of the untreated and heavy-liquid treated fractions are lower compared with most of the untreated aliquots from the heating experiments of the same sample (Fig. 3a, Table 3). Although the depletion in the two fractions may be explained by partial loss of Ar, it is not clear why the untreated bulk sample lost more radiogenic Ar than most of the the bulk untreated fractions used for the heating experiments.

The $\mathrm{K}$ and Ar contents of the clinoptilolite fractions were variably affected during the ionexchange experiments with the $1 \mathrm{M} \mathrm{Ca}-, \mathrm{Cs}-, \mathrm{K}-$, and Na-chloride solutions (Fig. 3a). Most of the Ca-, Cs-, K-, and Na-clinoptilolite samples from the three- and five-day exchanges exhibited minor variations in their radiogenic Ar contents except for the $\mathrm{Cs}$ - and $\mathrm{Na}$-clionoptilolite fractions exchanged for five days. Although the smaller amount of radiogenic Ar in the Na-clinoptilolite may be explained by loss of Ar, the source of the larger amount in the Cs-clinoptilolite is unclear. However, two of the untreated clinoptilolite fractions from the saturated $\left(100^{\circ} \mathrm{C} / 1 \mathrm{month}\right)$ and unsaturated $\left(50^{\circ} \mathrm{C} / 16\right.$ hours) heating experiments contain similar amounts of radiogenic Ar (Table 3). Thus, the larger amounts in the three fractions may be real, and most of the other samples lost 
some of their radiogenic Ar during the ion-exchange experiments. On the other hand, those samples with larger amounts of radiogenic Ar may be contaminated by few primary feldspar grains although the X-ray patterns do not indicate this to be the case. The larger amount of radiogenic $\mathrm{Ar}$ in the Cs-clinoptilolite fraction is not likely due to gain in radiogenic Ar because the similar ionic radius of $\mathrm{Cs}^{+}(1.91 \AA)$ compared with $\mathrm{Ar}(1.9 \AA)$ probably minimized loss and/or gain of $\mathrm{Ar}$ from the clinoptilolite structure. According to Barrer (1978), ions and molecules traverse the same channel and their access to the zeolite structure is dependent on the size and shape of the diffusing ion or molecule.

Despite less $\mathrm{K}^{+}$depletion, the Na-clinoptilolites indicate an opposite pattern of Ar depletion compared with the Cs-clinoptilolites. The Na-clinoptilolite exchanged for 5 days lost half of its Ar compared with a similar fraction exchanged for three days (Table 3). The significant loss of Ar may be related to the smaller ionic radius of $\mathrm{Na}(1.1 \AA$ or $1.24 \AA$, depending on the coordination number) and to loss of water. It is suggested that $\mathrm{Na}^{+}$and $\mathrm{Ca}^{2+}$ occupy water sites in a clinoptilolite structure during ion exchange, if there are no other locations, and that the high content of $\mathrm{Na}^{+}$and $\mathrm{K}^{+}$and their lower hydration energies result in less total water in clinoptilolite than a Ca-rich end member (Berger et al., 1970; Tsitsishvili et al., 1992).

Compared with the Cs- and Na-clinoptilolites, the Ar contents in the Ca- and $\mathrm{K}$ clinoptilolites exhibit less variability (Fig. 3a). However, the Ca-clinoptilolites contain lesser amounts of radiogenic Ar than the K-clinoptilolite fractions. The radiogenic Ar contents in the Kclinoptilolites exchanged for three and five days are almost identical and the samples contain amounts of radiogenic Ar similar to most of the untreated clinoptilolite fractions from the saturated and unsaturated heating experiments.

The results of the ion-exchange experiment suggest the possible effects of post-diagenetic chemical interactions between zeolites and major and trace element cations in ground water. The $\mathrm{K}_{2} \mathrm{O}$ contents of the ion-exchanged samples were affected significantly (Table 3 ). In the diagenetic environment, the effects of ground water chemistry on alkali zeolites can be evaluated by comparing the radiogenic Ar contents or isotopic ages of coexisting authigenic mineral phases (e.g., illite/smectite and K-feldspar) in the altered rock. Such studies can indicate whether the alkali zeolites gained or lost $\mathrm{K}$ and Ar during post-crystallization alteration. However, this type of 
information does not exist for zeolites of the Sucker Creek Formation and little can be said about the geological history of the clinoptilolite-rich sample used in this experiment.

Post-crystallization modification of the $\mathrm{K}_{2} \mathrm{O}$ and Ar contents of zeolites in the diagenetic environment may depend on 1) temperature, 2) ground and/or pore water composition, 3) permeable fluid pathways, and 4) fluid-rock interaction. Clauer (1982) reported a mid-Miocene diagenetic age for a phillipsite and implied that induration of the host rock was responsible for the cessation of diagenetic reactions between pore fluids and phillipsites in mid-Eocene ocean floor sediments. Similar interpretations were made by Ijima (1987) concerning the incomplete transformation of alkali zeolites to analcime in marine sediments, which he attributed to impermeability in the host rock and/or a slow rate of reaction that arrested the diagenetic reactions.

The radiogenic Ar contents of alkali zeolites may also be affected by post-diagenetic heating and/or dehydration as indicated by the preliminary results of the experiments. The zeolite-rich tuffs at Yucca Mountain are characteristic of a low-temperature diagenetic environment consisting of smectite, clinoptilolite, and opal-CT with an upper stability limit of about $100^{\circ} \mathrm{C}$ (Iijima, 1978; Bish, 1989). Because water appears to minimize Ar diffusion from the clinoptilolite structure, loss of Ar during dehydration may be a major factor contributing to the depletion of radiogenic $\mathrm{Ar}$ contents from K-bearing clinoptilolite fractions in unsaturated environment. Alternatively, clinoptilolite existing in a partially saturated environment may contain less water, facilitating the more rapid diffusion of Ar.

In one experiment, loss of Ar from a clinoptilolite fraction heated for 16 hours at $200^{\circ} \mathrm{C}$ is probably related to the loss of water from the mineral structure. This loss of Ar from clinoptilolite occurred at a temperature $\left(200^{\circ} \mathrm{C}\right)$ that is higher than the upper stability limit of alkali zeolites and other coexisting authigenic minerals (e.g., smectite and opal-CT). Dehydration is known to cause increased atomic displacement and disorder in the tetrahedral framework of alkali zeolites (Bish, 1988; Armbruster, 1993), that is likely to result in Ar loss from the framework structure. Variable isotopic ages (2-13 Ma) were measured on clinoptilolite fractions from the saturated and unsaturated zones at Yucca Mountain, Nevada, that have been attributed to dehydration of clinoptilolite in the unsaturated zone resulting in Ar loss and younger isotopic ages (WoldeGabriel et al., 1993). This conclusion is consistent with the preliminary experimental results reported here. 
According to Barrer and Vaughan (1969), Ar diffusion can be minimized by rehydration of clinoptilolite as long as it is not heated above $110^{\circ} \mathrm{C}$. This is consistent with the results of the older isotopic ages measured on clinoptilolite fractions from the saturated zone at Yucca Mountain (WoldeGabriel et al., 1993). Moreover, the importance of saturation is demonstrated by minimal Ar loss from clinoptilolite fractions that were heated at $100^{\circ} \mathrm{C}$ in a saturated environment for more than five months. Radiogenic Ar contents of clinoptilolite fractions from the saturated and unsaturated heating experiments (Figs. $3 \mathrm{~b}$ and $3 \mathrm{c}$ ) clearly reflect the variation pattern indicated by the clinoptililote K/Ar data from the saturated and unsaturated zones at Yucca Mountain. This similarity confirms the importance of water in maintaining the retention of Ar within K-bearing zeolites. Clinoptilolite isotopic ages increase toward the lower part of the unsaturated zone at Yucca Mountain (WoldeGabriel et al., 1993), and this may be related to the proximity of the dated samples to the static water level. The preliminary results from this study will be used in experiments that will be conducted to document Ar mobility in hydrated and dehydrated clinoptilolite fractions at different conditions that possibly reflect the zeolite diagenetic environment.

\section{SUMMARY AND CONCLUSIONS}

The radiogenic Ar contents from the clinoptilolite fractions used in the experiment represent minimum amounts and are consistent with loss of Ar. Results from the ion exchange indicate that $\mathrm{K}^{+}$contents are significantly modified compared with the Ar composition of the same samples. $\mathrm{K}$ bearing zeolites in a permeable diagenetic environment can be modified during water-rock interaction especially if the fluids are saline and/or alkaline in composition. Ar depletion was apparent in a clinoptilolite fraction dehydrated by heating at different temperatures. A similar result was obtained from a Na-clinoptilolite exchanged for five days.

Samples heated in a saturated environment at $100^{\circ} \mathrm{C}$ for various time periods indicate irregular variations in their Ar contents unlike those samples from the unsaturated heating. Water plays an important role in maintaining Ar retention in the clinoptilolite framework. This is consistent with the clinoptilolite K/Ar data from the saturated zone at Yucca Mountain that yield older isotopic ages compared with those samples from the same section in the unsaturated zone. 
Thus, if K-bearing zeolites are used in conjunction with other dateable coexisting authigenic minerals, information from such minerals may be useful in understanding the diagenetic history of a zeolite-rich environment.

\section{ACKNOWLEDGMENTS}

This work was supported by the Yucca Mountain Site Characterization Project Office as part of the Civilian Radioactive Waste management Programs of the U.S. Department of Energy. This project is managed by the U.S. Department of Energy Yucca Mountain Site Characterization Project. Comments by David Bish, David Broxton, David Vaniman, and Schon Levy improved the manuscript. In compliance with LANL-YMP-QP-03.23, R2, the DTN \# is LA000000000121.001.

\section{REFERENCES}

Altaner, S. P. and Grim R. E., "Mineralogy, chemistry, and diagenesis of tuffs in the Sucker Creek Formation (Miocene), Eastern Oregon," Clays and Clay Minerals 38, No. 6, 561-572 (1990), YMP accession no. MOL.19941220-0115.

Ames, L.L., Jr., "Cation sieve properties of the open zeolites chabazite, mordenite, erionite, and clinoptilolite," Am. Mineral. 45, 689-700 (1961), YMP accession no. NNA.921026.0010.

Armbruster, T., "Dehydration mechanism of clinoptilolite and heulandite: single-crystal X-ray study of Na-poor, Ca-, K-, Mg-rich clinoptilolite at 100K," Am. Mineral. 78, 260-264 (1993), YMP accession no. NNA.930625.0035.

Barrer, R.M., and Vaughan, J.H., "Sorption and diffusion of rare gases in heulandite and stilbite," Surface Science 14, 77-92 (1969), YMP accession no. NNA.930629.0002.

Barrer, R. M., "Cation-exchange equilibria in zeolites and feldspathoids," In Natural Zeolites: Occurrences, Properties, Use (eds. Sand, L. B. and Mumpton, F.A.), Pergamon Press, Elmsford, New York, 385-395 (1978). Readily Available.

Bell, T. E., "Deposition and diagenesis in the Brush Basin Member and upper part of the Westwater Canyon Member of the Morrison Formation, San Juan basin, New Mexico," In A Basin Analysis Study-The Morrison Formation, Grants Uranium Region, New Mexico (eds. C. E. Turner-Peterson, E.S. Santos, and N. S. Fishman); American Association of Petroleum Geologists Studies in Geology 22, 77-91 (1986), YMP accession no. MOL.19941220-0116. 
Bernat, M., Bieri, R. H., Koide, M., Griffin, J. J., and Goldberg, E. D., "Uranium, thorium, K, and Ar in marine phillipsites," Geochem. Cosmochim. Acta 34, 1063-1071 (1970), YMP accession no. NNA.930629.0003.

Berger, I. A., Chandler, J. C., and Zubovic, P., “An infrared study of water in heulandite and clinoptilolite. Am. Mineral. 55, 825-840 (1970), YMP accession no. MOL.19941220.0117.

Bish, D.L., "Effects of composition on the dehydration behavior of clinoptilolite and heulandite," In Occurrence, Properties, and Utilization of Natural Zeolites (eds., Kallo, D., and Sherry, H.S.), Akadémiai Kiadó, Budapest, 565-576 (1988), YMP accession no. NNA.890525.0001.

Bish, D.L., "Evaluation of past and future alterations in tuff at Yucca Mountain, Nevada, based on clay mineralogy of drill cores USW G-1, G-2, and G-3," Los Alamos National Laboratory Report, LA-10667, 40 p (1989), YMP accession no. NNA.890126.0207.

Bish, D. L. and Aronson, J. L, "Paleogeothermal and paleohydrologic conditions in silicic tuff from Yucca Mountain, Nevada," Clays and Clay Minerals 41, 148-161 (1993), YMP accession no. NNA.940323.0292.

Boles, J. R., "Composition, optical properties, cell dimension, and thermal stability of some heulandite-group zeolites," Am. Mineral. 57, 1463-1493 (1972), YMP accession no. MOL.19941220.0118.

Boles, J. R. "Zeolites in low-grade metamorphic rocks," In Mineralogy and Geology of Natural Zeolites (eds., Mumpton, F. A.), Mineralogical Society of America 4, 103-134 (1977), YMP accession no. MOL.1994122.0119.

Clauer, N., "Strontium isotopes of Tertiary phillipsites from the Southern Pacific: Timing of the geochemical evolution," J. Sed. Petrol. 88, $1003-1009$ (1982), YMP accession no. NNA.930720.0001.

Cox, A. and Dalrymple, G. B., "Statistical analysis of geomagnetic reversal data and the precision of potassium-argon dating," J. Geophys. Res. 72, No. 10, 2603-2614 (1967), YMP accession no. NNA.930629.0006.

Elliot, C. W., Aronson, J. L., Matisoff, G., and Gautier, D. L., "Kinetics of the smectite to illite transformation in the Denver basin: clay mineral, K-Ar data, and mathematical model results," Amer. Associ. of Petr. Geol. Bull. 75, 436-462 (1991), YMP accession no. NNA.930625.0037.

Feng, X. and Savin, S. M., "Oxygen isotope studies of zeolite, stilbite, analcime, heulandite, and clinoptilolite: II. Kinetics and mechanisms of isotopic exchange between zeolites and water vapor," Geoch. et Cosmochim. Acta 57, 4219-4238 (1993), YMP accession no. MOL.19941220.0120. 
Govindaraju, K., Special issue of Geostandards Newsletter, XIII, 21 (1989), YMP accession no. MOL.19941220.0121.

Gundogdu, M. N., Bonnet-Courtois, C., and Clauer, N., "Isotope and chemical signatures of sedimentary smectite and diagenetic clinoptilolite of lacustrine Neogene basin near Bigadic, Western Turkey," Appl. Geochem. 4, 635-644 (1989), YMP accession no. NNA.930629.0009.

Hay, R. L., "Stratigraphy and zeolites diagenesis of the John Day Formation of Oregon," Univ. of Calif. Publ. Geol. Sci. 42, 199-262 (1963), YMP accession no. NNA.930629.0009.

Hay R.L., "Geologic occurrences of zeolites," In Natural Zeolites: Occurrences, Properties, Use (eds., Sand L. B. and Mumpton F. A.); Pergamon Press, Elmsford, New York, 135-143 (1978), YMP accession no. NNA.870406.0096.

Hoffman, J., Hower, J., and Aronson, J. L., "Radiometric dating of time of thrusting in the disturbed belt of Montana," Geology 4, 16-20 (1976), YMP accession no. MOL.19941220.0122.

Iijima, A., "Geological occurrences of zeolites in marine environments," In Natural Zeolites: Occurrences, Properties, Use (eds., Sand, L.B., and Mumpton, F.A.); Pergamon Press, Elmsford, New York, 175-198 (1978), Readily Available.

Koul, S. L., Chdderton, L. T., and Brooks, C. K., "Fission track dating of zeolites" Nature 294, 347-350 (1981), YMP accession no. NNA.930625.0038.

Mumpton, F. A., "Natural zeolites: a new industrial mineral commodity," In Natural Zeolites: Occurrences, Properties, Use (eds. Sand, L. B. and Mumpton, F.A.); Pergamon Press, Elmsford, New York, 3-27 (1978). Readily Available.

Odin, G. S., and 35 collaborators, "Interlaboratory standards for dating purposes," In Numerical Dating in Stratigraphy (ed., Odin, G. S.), Wiley, New York, 124-150 (1982). Readily Available.

Sheppard, R. A., Gude, A. J. 3rd, and Mumpton, F. A., "Sheaville zeolite deposit, Sheaville, Oregon," In Zeo-Trip '83 (ed. Mumpton, F. A.), State University of New York, Brockport, 25-31 (1983), YMP accession no. MOL.19941220.0123.

Steiger, R.H., and Jager, E., "Subcommission on geochronology: Convention on the use of decay constants in geo- and cosmochronology," Earth and Planet. Sci. Lett. 36, 359-362 (1977), YMP accession no. NNA.930629.0016.

Tsitsishvili, G. V., Andronikashvili, T. G., Kirov, G. N., and Filizova, L. D., "Natural Zeolites," Ellis Horwood, New York, 18-34 (1992). Readily Available.

Turner, C.E. and Fishman, N. S., 'Jurassic Lake T'oo'dichi': A large alkaline, saline lake, Morrison Formation, eastern Colorado Plateau," Geological Society of America Bulletin, 103, 538-558 (1991), YMP accession no. MOL.19941220.0124. 
Vaughan, D. E. W., "Properties of natural zeolites," In Natural Zeolites: Occurrences, Properties, Use (eds. Sand, L. B. and Mumpton, F.A.); Pergamon Press, Elmsford, New York, 353371 (1978), YMP accession no. NNA.921026.0011.

WoldeGabriel, G. and Goff, F., "Temporal relations of volcanism and hydrothermal systems in two areas of the Jemez volcanic field, New Mexico," Geology 17, 986-989 (1989), YMP accession no. NNA.930629.0019.

WoldeGabriel, G, Broxton, D. E., Bish D. L., and Chipera, S. J., "Mineralogy and clinoptilolite K/Ar results from Yucca Mountain, Nevada, USA: A potential high-level radioactive waste repository site," Los Alamos National Laboratory Report, LA-12652, 44 p. (1993), YMP accession no. NNA.930921.0037. 